\title{
VITAMIN D3 LEVELS IN TWO DIFFERENT ETHNIC POPULATIONS- A BIRD'S EYE VIEW ON SOCIO- CULTURAL INFLUENCES
}

\author{
Rajendran Subramaniam¹, Babu Krishnan²
}

${ }_{1}^{1}$ Associate Professor, Department of Internal Medicine, Government Villupuram Medical College, Mundiyampakkam, Villupuram. ${ }^{2}$ Assistant Professor, Department of Internal Medicine, Government Villupuram Medical College, Mundiyampakkam, Villupuram.

\section{ABSTRACT}

\section{BACKGROUND}

The prevalence of Vitamin D deficiency has steadily risen in last few years. Environmental factors like temperate climate, indoor lifestyle, diet prejudice as well as human behavioural patterns among ethnic groups significantly influence Vitamin D3 levels.

In this study, we aimed to compare Vitamin D3 levels between two ethnic populations. Group 1 comprised of Islamic ladies who strictly adhered to purdah lifestyle. Group 2 was made up of matched non-Islamic ladies of lower socioeconomic strata with predominant outdoor labour work.

\section{MATERIALS AND METHODS}

This is a cross-sectional comparative study. In view of financial and logistic constraints, the sample size was chosen for convenience; 50 Islamic women and same number of non-Islamic women who attended the female OP clinics at Government Villupuram Medical College were interviewed and eligibility ascertained. After obtaining informed consent, detailed physical examination was done and findings documented in standard case proforma. Their serum samples were collected and analysed for Vitamin D3 levels and serum calcium. The results were pooled and analysed using SPSS software version 20. Independent ' $\mathrm{t}$ ' test was used to compare two groups' age, BMI, Vitamin D3 levels and serum calcium variables to find out if there is any significant difference between them. The Pearson's correlation coefficient was used to derive relationship between BMI and Vitamin D3 levels. $P$ value $<0.05$ is considered for significant.

\section{RESULTS}

A total of 100 women were studied in the age group of 20 - 80 years. The mean age of the study group was 45.38 . The Body Mass Index of Group 1 was $29.19+/-5.18$ [Mean +/- SD], whereas in Group 2 it was $24.84+/-3.85 ; 82 \%$ of candidates in C1 were overweight or obese compared to only $48 \%$ in $\mathrm{C} 2$ [P $<0.001]$. The mean Vitamin D3 in C1 was $22.35+/-6.89$ and that of $\mathrm{C} 2$ being $25.51+/-7.47$ [p $<0.05$ ]; $96 \%$ of C1 candidates and 86\% of C2 candidates had subnormal D3 values. There was a significant negative correlation between BMI and Vitamin D3 levels in C1 [r= -0.54, 2-tailed].

\section{CONCLUSION}

This study revealed that the prevalence of Vitamin D3 deficiency was almost the same in two different ethnic groups of women. However, the magnitude of deficiency was much more in Islamic women. The strong negative relationship between obesity and Vitamin D3 levels was also ascertained.

\section{KEYWORDS}

Vitamin D3, Islamic Women, Obesity.

HOW TO CITE THIS ARTICLE: Subramaniam R, Krishnan B. Vitamin D3 levels in two different ethnic populations- a bird's eye view on socio-cultural influences. J. Evolution Med. Dent. Sci. 2017;6(79):5580-5583, DOI: 10.14260/jemds/2017/1211

\section{BACKGROUND}

Vitamin D is a fat-soluble vitamin that is naturally present in very few foods, added to others and available as a dietary supplement. It is synthesised by the skin due to the effect of ultraviolet rays from the sun on the epithelial cells. Vitamin D obtained by this route or by oral nutrients must undergo activation in the form of 2 hydroxylations before they are metabolically active. The reaction first occurs in the liver and converts vitamin D to 25-hydroxyvitamin D [25(OH)D],

\section{'Financial or Other Competing Interest': None.}

Submission 15-08-2017, Peer Review 18-09-2017,

Acceptance 25-09-2017, Published 30-09-2017.

Corresponding Author:

Dr. Babu Krishnan,

Assistant Professor,

Department of Internal Medicine,

Government Villupuram Medical College,

Mundiyampakkam,

Villupuram-605602, Tamilnadu.

E-mail: dr_babu73@yahoo.com

DOI: $10.14260 /$ jemds $/ 2017 / 1211$

\section{(c) $($ ) $\ominus$}

also known as calcidiol. The second occurs primarily in the kidney and forms the physiologically active 1, 25dihydroxyvitamin $\mathrm{D}\left[1,25(\mathrm{OH})_{2} \mathrm{D}\right]$, also known as calcitriol.[1]

There has been a global decline in vitamin D3 levels in the past few decades. Environmental factors like temperate climate, indoor lifestyle, diet prejudice, etc. have a bearing on this effect. Furthermore, behavioural patterns among ethnic groups significantly influence the generation of Vitamin D3 among people. For example, Islamic ladies who practise purdah system stand to face considerable disadvantage in this regard. Their predominantly indoor lifestyle and dark whole-body clothing [burqa] are impediments for sun exposure.

\footnotetext{
Aim

In this study, we aimed to compare the Vitamin D3 levels among two age matched groups of ladies. Group 1 comprised of Islamic ladies who strictly adhered to purdah lifestyle. Group 2 was made up of age matched non-Islamic ladies of lower socioeconomic strata with predominant outdoor labour work.
} 


\section{MATERIALS AND METHODS}

This is a cross-sectional comparative study. In view of financial and logistic constraints, the sample size was chosen for convenience.

\section{Inclusion Criteria}

1. Islamic women who practise burkah system.

2. Treatment naïve patients who have not been tested for Vitamin D3 levels earlier.

3. Non-Islamic women who are manual labourers and have predominant outdoor lifestyle [Agriculture/Construction workers].

\section{Exclusion Criteria}

1. Women with comorbid illnesses like diabetes, chronic kidney disease, IHD.

2. Women who are on vitamin supplements.

50 Islamic women who attended the female OP clinics at Government Villupuram Medical College for various complaints were interviewed and eligibility ascertained. After obtaining informed consent detailed physical examination was done and findings documented in standard case proforma. Their serum samples were collected and analysed for Vitamin D3 levels and serum calcium. Likewise, 50 nonIslamic ladies who were manual labourers were interviewed and assessed for inclusion in the study. Eligible candidates were examined and serum collected for the same tests with their informed consent. The results were pooled and analysed using SPSS software version 20.0. Independent ' $\mathrm{t}$ ' test was used to compare two groups' age, BMI and Vitamin D3 levels, serum calcium variables to find out if there is any significant difference between them. The Pearson's correlation coefficient was used to derive relationship between BMI and Vitamin D3 levels. P value $<0.05$ is considered for significant.

\section{RESULTS}

A total of 100 women were studied in the age group of $20-80$ years. The mean age of the study group was 45.38. The Body Mass Index of Group 1 was $29.19+/-5.18$ [Mean +/- SD], whereas in Group 2 it was $24.84+/-3.85$; $82 \%$ of candidates in C1 were overweight or obese compared to only $48 \%$ in C2 $[\mathrm{P}<0.001]$. The mean Vitamin D3 in C1 was 22.35+/- 6.89 and that of C2 being $25.51+/-7.47$ [p $<0.05]$; $96 \%$ of $\mathrm{C} 1$ candidates and $86 \%$ of $\mathrm{C} 2$ candidates had subnormal D3 values. There was a significant negative correlation between BMI and Vitamin D3 levels in C1 [r= -0.54, 2-tailed] the serum calcium was subnormal in the majority of the study population [mean $8.93+/-0.38$ ]; however, no significant difference between the 2 groups was observed. The results are summarised in Table 1.

\section{DISCUSSION}

The primary role of vitamin D3 is to promote absorption of calcium in the gut and maintain adequate serum calcium and phosphate concentrations to enable normal mineralisation of bone and to prevent hypocalcaemic tetany. It is imperative for normal bone growth and bone remodelling by osteoblasts and osteoclasts.[1,2] Deficiency of vitamin D3 will lead to demineralisation of bone which can become thin, brittle or malformed. Vitamin D sufficiency prevents rickets in children and osteomalacia in adults.[1] Together with calcium, vitamin $\mathrm{D}$ also helps protect older adults from osteoporosis.

Serum concentration of $25(\mathrm{OH}) \mathrm{D}$ is the best indicator of vitamin D status. It reflects vitamin D produced cutaneously and that obtained from food and supplements.[1] One 2008 review has proposed the following categories for-

\begin{tabular}{|c|c|c|c|}
\hline Variables & Group 1 & Group 2 & Significance \\
\hline Age & 45.58 & 45.38 & $\mathrm{P}>0.05 \mathrm{~ns}$ \\
\hline BMI & $29.19+/-5.18$ & $24.84+/-3.85$ & $\mathrm{P}<0.001$ \\
\hline BMI > 24.5 & $41(82 \%)$ & $24(48 \%)$ & $\mathrm{P}<0.001$ \\
\hline Vitamin D3 & $22.35+/-6.89$ & $25.51+/-7.47$ & $\mathrm{P}<0.05$ \\
\hline $\begin{array}{c}\text { Vitamin D3 < } \\
30 \text { ug }\end{array}$ & 48 (96\%) & $43(86 \%)$ & $\mathrm{P}>0.05 \mathrm{~ns}$ \\
\hline $\begin{array}{c}\text { Serum } \\
\text { Calcium }\end{array}$ & $8.93+/-0.38$ & $8.73+/-0.39$ & $\mathrm{P}<0.05$ \\
\hline BMI vs D3 & $\mathrm{R}=-0.542^{* * *}$ & $\mathrm{R}=0.186$ & $\mathrm{P}<0.01$ \\
\hline
\end{tabular}

Table 1. Comparison of Data between Groups 1 and 2 ns: non-significant

Hypovitaminosis D: Insufficient 25 - $74 \mathrm{nmol} / \mathrm{L}(10$ $29.6 \mathrm{ng} / \mathrm{mL})^{[3]}$ As of 2011, most reference labs used the $30 \mathrm{ng} / \mathrm{mL}$ standard.[4]

There is a lack of consensus regarding the appropriate level of Vitamin D3 for optimal health. They are likely to vary at each stage of life, depending on the physiological measures selected. ${ }^{[1,2,5]}$ Also, as stated earlier, while serum 25(OH)D functions as a biomarker of exposure to vitamin D (from sun, food and dietary supplements), the extent to which such levels serve as a biomarker of effect (i.e. health outcomes) is not clearly established.[1]

A growing body of research suggests that vitamin D might play some role in the prevention and treatment of type 1 and type 2 diabetes, hypertension, glucose intolerance, multiple sclerosis and other medical conditions. $[6,7,8,9,10,11,12]$ However, the authenticity of this is not yet established pending wellstructured randomised clinical trials, which are considered to be more definitive.[1] Until such trials are conducted, the implications of the available evidence for public health and patient care will be debated. One meta-analysis found use of vitamin D supplements to be associated with a statistically significant reduction in overall mortality from any cause,[13] but a reanalysis of the data found no association. A systematic review of these and other health outcomes related to vitamin $\mathrm{D}$ and calcium intakes, both alone and in combination, was published in August 2009.

Most people meet at least some of their vitamin D needs through exposure to sunlight.[1,2] Ultraviolet (UV) B radiation with a wavelength of 290 - 320 nanometres penetrates uncovered skin and converts cutaneous 7-dehydrocholesterol to previtamin $\mathrm{D}_{3}$, which in turn becomes vitamin $\mathrm{D}_{3 .} .^{[1]}$ The synthesis of vitamin D3 by the skin is confounded by many factors like climate, time of day, length of day, cloud cover, smog, skin melanin content and sunscreen.[1] Nevertheless, geographic location does not guarantee a steady state level of vitamin D3 even among dwellers of equatorial regions. The capacity to synthesise and store vitamin D3 is particularly enhanced in the spring, summer and fall months even in the far north latitudes.[1]

Those most likely to be affected by vitamin D deficiency are people with little or no solar exposure. Climate, dress habits, avoiding sun exposure and too much sunscreen 
protection limit the production of vitamin D.[14,5,15] Homebound individuals, women who wear long robes and head coverings for religious reasons [burqa] and people with occupations that limit sun exposure are unlikely to obtain adequate vitamin D from sunlight.[16,17] The dark skinned races are at a significant disadvantage as the greater amount of melanin pigment serves as an impediment to absorb UVB rays involved in the manufacture of vitamin.[1] Various reports consistently show lower serum 25(OH)D levels in persons identified as black compared with those identified as white. It is not clear that lower levels of 25(OH)D for persons with dark skin have significant health consequences. Those of African-American ancestry, for example, have reduced rates of fracture and osteoporosis compared with Caucasians (see section below on osteoporosis). Ingesting RDA levels of vitamin $\mathrm{D}$ from foods and/or supplements will provide these individuals with adequate amounts of this nutrient.

This finding was substantiated in our study, wherein Group 1 [Islamic ladies] recorded a mean Vitamin D3 value of $22.35+/-6.89$ that of Group 2 being $25.51+/-7.47[p<0.05]$.

Contrary to common conception, in our study the prevalence of Vit D3 deficiency was almost the same for two widely variant populations. The mean Vitamin D3 in C1 was $22.35+/-6.89$ and that of C2 being $25.51+/-7.47 ; 96 \%$ of $\mathrm{C} 1$ candidates and $86 \%$ of $\mathrm{C} 2$ candidates had subnormal D3 values. However, the magnitude of deficiency was more among Group 1 patients compared to Group 2. The probable explanation was that Islamic women of Group 1, though disadvantaged by limited sun exposure, were compensated by animal protein rich diet a good source of dietary Vitamin D. In Group 2 though the women spent most of their time in outdoor manual work, their Vitamin D3 source was jeopardised by dark complexion as well as poor dietary replenishment.

Obese individuals have lower levels of the circulating form of vitamin $\mathrm{D}$, due to the likelihood of decreased bioavailability of vitamin D3 from food and sunlight due to the distribution in adipose tissue.[18] $\mathrm{A}$ population-based Group study in Spain tested 1226 subjects to determine is associated with an increased risk of developing obesity. ${ }^{[19]} \mathrm{A}$ body mass index $\geq 30$ is associated with lower serum 25(OH)D levels compared with non-obese individuals; obese people require heavier doses of vitamin D supplements to attain comparable serum levels with their lean counterparts.[19] Obesity does not affect skin's capacity to synthesise vitamin D, but greater amounts of subcutaneous fat sequester more of the vitamin and alter its release into the circulation. Obese individuals who have undergone gastric bypass surgery may become vitamin D deficient over time without a sufficient intake of this nutrient from food or supplements, since part of the upper small intestine where vitamin D is absorbed is bypassed and vitamin D mobilised into the serum from fat stores may not compensate over time.[20,21]

True to this testimony, in our study we found a strong relationship with obesity and decreased Vitamin D3 values. There was a significant negative correlation between BMI and Vitamin D3 levels in C1 [ $r=-0.54]$. However, there are multiple confounding factors determining the observation and a simple cause and effect relationship between Vitamin D3 and obesity would be an oversimplified hypothesis.

\section{Limitation}

This was a preliminary investigative effort to derive insights into the prevalence of Vit D3 deficiency patterns among populations. The sample size was limited and the findings were based on selective patient groups, who attended the tertiary care hospital outpatient clinic. These findings have to be substantiated by larger multicentric research efforts involving all the tiers of health care system. It is then that the observations could be extrapolated to the general population.

\section{CONCLUSION}

Vitamin D3 deficiency is rampant paying little respect to sociocultural barriers. This study revealed that the prevalence of Vitamin D3 deficiency was almost the same in two different ethnic groups of women. However, the magnitude of the deficiency was much more in Islamic women who practised the purdah system of lifestyle. The strong negative relationship between obesity and Vitamin D3 levels was also ascertained.

\section{ACKNOWLEDGEMENTS}

The authors acknowledge all staffs of the Departments of Internal Medicine and Biochemistry, Government Villupuram Medical College and Hospital for their cooperation and effort in conducting this study. They acknowledge the help of Dr. Ashok, statistician for data analysis.

\section{REFERENCES}

[1] Institute of Medicine, Food and Nutrition Board. Dietary reference intakes for Calcium and Vitamin D. Washington, DC: National Academy Press 2010.

[2] Cranney A, Horsely T, O'Donnell S, et al. Effectiveness and safety of Vitamin D. in relation to bone health. The University of Ottawa, Evidence-based Practice Center under Contract No. 290-02.0021. AHRQ Publication No. 07-E013. Rockville, MD: Agency for Healthcare Research and Quality, 2007. Evidence Report Technology Assessment 2007;158:1-235.

[3] Stroud ML, Stilgoe S, Stott VE, et al. Vitamin D - a review. Australian Family Physician 2008;37(12):1002-5.

[4] Holick MF, Binkley NC, Bischoff-Ferrari HA, et al. Evaluation, treatment, and prevention of Vitamin D deficiency: an Endocrine Society clinical practice guideline. The Journal of Clinical Endocrinology and Metabolism 2011;96(7):1911-30.

[5] Bandgar TR, Shah NS. Vitamin D and hip fractures: Indian scenario. Journal of the Association of Physicians of India 2010;58:535-7.

[6] Hyppönen E, Läärä E, Reunanen A, et al. Intake of vitamin $\mathrm{D}$ and risk of type 1 diabetes: a birth-cohort study. Lancet 2001;358(9292):1500-3.

[7] Pittas AG, Dawson-Hughes B, Li T, et al. Vitamin D and calcium intake in relation to type 2 diabetes in women. Diabetes Care 2006;29(3):650-6.

[8] Krause R, Bühring $M$, Hopfenmüller $W$, et al. Ultraviolet $\mathrm{B}$ and blood pressure. Lancet 1998;352(9129):709-10. 
[9] Chiu KC, Chu A, Go VL, et al. Hypovitaminosis D is associated with insulin resistance and beta cell dysfunction. Am J Clin Nutr 2004;79(5):820-5.

[10] Munger KL, Levin LL, Hollis BW, et al. Serum 25hydroxyvitamin D levels and risk of multiple sclerosis. JAMA 2006;296(23):2832-8.

[11] Merlino LA, Curtis J, Mikuls TR, et al. Vitamin D intake is inversely associated with rheumatoid arthritis: results from the Iowa Women's Health Study. Arthritis Rheum 2004;50(1):72-7.

[12] Schleithoff SS, Zittermann A, Tenderich G, et al. Vitamin D supplementation improves cytokine profiles in patients with congestive heart failure: a doubleblind, randomized, placebo-controlled trial. Am J Clin Nutr 2006;83(4):754-9.

[13] Autier P, Gandini S. Vitamin D supplementation and total mortality: a meta-analysis of randomized controlled trials. Arch Intern Med 2007;167(16):17307.

[14] Mishal AA. Effects of different dress styles on Vitamin $D$ levels in healthy young Jordanian women. Osteoporosis International 2001;12(11):931-5.

[15] Cashman KD. Vitamin D in childhood and adolescence. Postgraduate Medical Journal 2007;83(978):230-5.
[16] Webb AR, Kline L, Holick MF. Influence of season and latitude on the cutaneous synthesis of vitamin D3: exposure to winter sunlight in Boston and Edmonton will not promote vitamin D3 synthesis in human skin. J Clin Endocrinol Metab 1988;67(2):373-8.

[17] Webb AR, Pilbeam C, Hanafin N, et al. An evaluation of the relative contributions of exposure to sunlight and of diet to the circulating concentrations of 25hydroxyvitamin $\mathrm{D}$ in an elderly nursing home population in Boston. Am J Clin Nutr 1990;51(6):107581.

[18] Wortsman J, Matsuoka LY, Chen TC, et al. Decreased bioavailability of vitamin D in obesity. The American Journal of Clinical Nutrition 2000;72(3):690-3.

[19] Molero GL, Rojo G, Morcillo S, et al. Vitamin D deficiency and obesity. Atherosclerosis 2014;235(2):e212.

[20] Malone M. Recommended nutritional supplements for bariatric surgery patients. Ann Pharmacother 2008;42(12):1851-8.

[21] Compher CW, Badellino KO, Boullata JI. Vitamin D and the bariatric surgical patient: a review. Obes Surg 2008;18(2):220-4. 